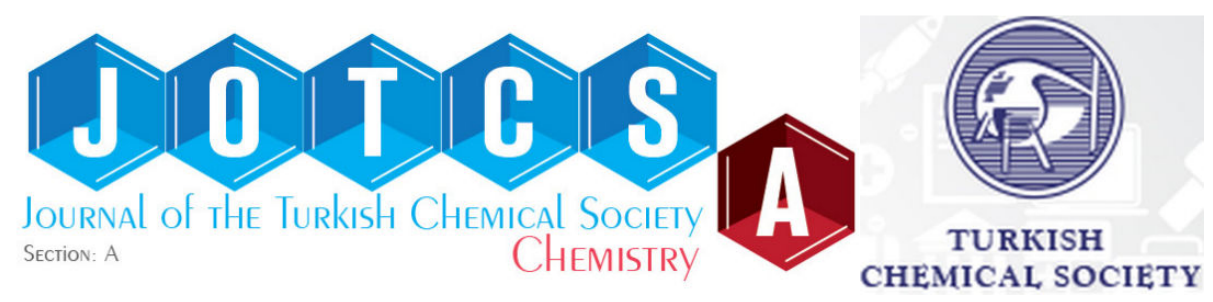

\title{
Effect of Collection Time on Chemical Composition and Antibacterial Activity of Flower Essential Oil of Ocimum canum (Sims) Grown in Nigeria
}

\author{
Usman Lamidi Ajao ${ }^{1 *}$, Yusuf Abdulrauf Olaniyi ${ }^{1}$, Saliu Bola Kudirat ${ }^{2}$, Olanipekun Bolatito Eunice ${ }^{3}$ \\ Elelu Nusirat ${ }^{4}$.
}

${ }^{1}$ Department of Chemistry, Faculty of Physical Sciences University of Ilorin, PMB 1515 Ilorin, Nigeria.

${ }^{2}$ Department of Microbiology, Faculty of Life Sciences, University of Ilorin, PMB 1515 Ilorin, Nigeria.

${ }^{3}$ Department of Chemical, Geological and Physical Sciences, Kwara State University, Malete, Nigeria.

${ }^{4}$ Department of Veterinary Public Health and Preventive Medicine, Faculty of Veterinary Medicine University of Ilorin, PMB 1515, Nigeria.

\begin{abstract}
Flowers $(1000 \mathrm{~g})$ of Ocimum canum harvested at different times ( $7 \mathrm{am}, 10 \mathrm{am}, 1 \mathrm{pm}$, $4 \mathrm{pm}$, and $7 \mathrm{pm}$ ) in a day were separately hydrodistilled and yielded $0.19-0.27 \%(\mathrm{w} / \mathrm{w})$ of essential oils. GC and GC-MS analyses revealed that the oils were predominated by oxygenated monoterpenoids (51.2-74.4\%). Hydrocarbon monoterpenoids constituted $6.2-10.2 \%$ of the oils. Percentage composition of hydrocarbon and oxygenated sesquiterpenoids in the oils were in the range of $1.3-22.0 \%$. The most abundant constituent of the oils was linalool $(40.5-58.7 \%)$. Other principal constituents were as follows: Limonene (0.6 -7.5\%), terpinen-4-ol $(1.4-5.6 \%)$, eugenol $(4.4-8.9 \%)$, geranyl acetate $(0.2-4.9 \%)$, a-trans-bergamotene $(3.2-9.4 \%)$ and $(E)$-isoeugenol $(4.1-5.5 \%)$. The predominance of linalool in the oils showed that the oils were of linalool chemotype. Antibacterial activity of the oils was evaluated against Staphylococcus aureus and Escherichia coli using agar diffusion method. Irrespective of the time of collection of the flower, the oils were found to be active against the tested organisms. However, they are more active on Escherichia coli than Staphylococcus aureus. The activity of the oils on the organisms was concentration-dependent.
\end{abstract}

Keywords: Ocimum canum; Chemotype; linalool; terpene synthase; antibacterial activity.

Submitted: September 29, 2016. Revised: October 25, 2016. Accepted: 07 November, 2016.

Cite this: Usman L, Yusuf A, Saliu B, Olanipekun B, Elelu N. Effect of Collection Time on Chemical Composition and Antibacterial Activity of Flower Essential Oil of Ocimum canum (Sims) Grown in Nigeria. JOTCSA. 2017;4(1):149-64.

DOI: to be assigned.

*Corresponding author. E-mail: usmanlamidi@unilorin.edu.ng, tel: +2348035032378. 


\section{INTRODUCTION}

Ocimum canum is an annual, odorous herb with several folkloric uses (1). They are used in treating conjunctivitis and headaches (2). The aerial parts of the plant are used as febrifuge and as an ingredient of many remedies of cold and sinusitis. An infusion of its leaves is used as a diaphoretic $(3,4)$. Biochemical and biological activities of the plant extracts account for their use in herbal medicine (5-7). The presence of phenolics, flavonoids, tannins and terpenoids that were established in the plant extracts is responsible for the activities exhibited by the plant (8).

The existence of linalool, eugenol, trans-methylcinnamate, methyl chavicol, eucalyptol, and camphor chemotypes of leaf oil of $O$. canum have been reported in Rwanda, Nigeria, Sao Tome, Brazil, India, and Cameroon (5, 9-14). Similarly, linalool, cis- and trans- piperitol chemotypes of flower oil of the plant grown in Rwanda and Burkina-Faso have been discovered $(9,15)$.

Variation in the chemotypes of the oils is attributable to environmental and physiological factors at various locations of the plant that bears the essential oils (5). These factors determine the activity of the enzyme that facilitates the biosynthesis of terpenoid constituents of essential oils from their respective precursors in plants (16). Hence, the factors could cause a variation in phytochemical profiles and biological activities of the oils. At a particular plant location, the factors could vary from time to time in a day. It is on the basis of this that this work aimed at monitoring the effect of collection time on the chemical composition and antibacterial activity of essential oil from flower of the plant on Escherichia coli and Staphylococcus aureus.

\section{MATERIALS AND METHODS}

\section{Sample Collection and Preparation}

Flowers of $O$. canum were harvested from its mature plant at park and garden of University of Ilorin, Ilorin, Kwara State Nigeria. The harvests were carried out at various times in a day ( 7 am, $10 \mathrm{am}, 1 \mathrm{pm}, 4 \mathrm{pm}$, and $7 \mathrm{pm}$ ). Identification of the plant was done in the herbarium of Plant Biology Department, University of Ilorin, Ilorin where a voucher sample was deposited (UILH/001/608). The harvested samples were separately pulverized. The test organisms were obtained from the culture collection of the Department of Microbiology, University of Ilorin. The organisms were isolated and characterized by colonial, microscopic, and biochemical techniques in a previous study (17). 


\section{Isolation of the Oil}

$1000 \mathrm{~g}$ of each of the pulverized flowers of Ocimum canum was hydro-distilled for 3 hours in a Clevenger-type apparatus, according to the British Pharmacopoeia specification (18). The resulting oil from each sample was collected, preserved in a sealed sample tube, and stored under refrigeration until analysis.

\section{Gas chromatography (GC) analysis}

Essential oil from each of the harvests was diluted in $\mathrm{n}$-hexane by 1000 -fold and subjected to GC analysis. The GC analyses were performed on an Orion micromat 412 double focusing gas chromatography system fitted with two capillary columns coated with Cp- Sil 5 and Cp-Sil 19 (fused silica, $25 \mathrm{~m} \times 0.25 \mathrm{~mm}, 0.15 \mu \mathrm{m}$ film thickness) and flame ionization detector (FID). The volume injected was $0.2 \mu \mathrm{L}$, and the split ratio was 1:30. Oven temperature was programmed from $50-230{ }^{\circ} \mathrm{C}$ at $3{ }^{\circ} \mathrm{C} / \mathrm{min}$ using hydrogen as a carrier gas. Injection and detector temperatures were maintained at $200^{\circ} \mathrm{C}$ and $250^{\circ} \mathrm{C}$, respectively. Qualitative data were obtained by electronic integration of FID area percent without the use of correction factors.

\section{Gas Chromatography - Mass Spectrometry (GC/MS) Analysis}

A Hewlett - Packard HP 5890A GC, interfaced with a VG analytical 70-250s double focusing mass spectrometers was used. The MS operating conditions were: ionization voltage $70 \mathrm{eV}$, ion source and transfer line temperature was maintained at $230{ }^{\circ} \mathrm{C}$. The GC operating conditions were identical with those of GC analyses. The MS data were acquired and processed by on-line desktop with a computer equipped with disk memory. The percentage composition of the oils' constituents were computed in each case from GC peak areas. The identification of the components was based on comparison of retention indices (determined relative to the retention times of series of $n$ alkanes) and mass spectra with those of authentic samples and with data from the literature (1921).

\section{Antibacterial Assay (Agar Diffusion Method)}

Antibacterial activity of the oils was determined using agar diffusion method described by Sartoratto et al. (22) Inoculums were prepared with the fresh cultures of bacteria, grown in nutrient broth for 24 hours at $37{ }^{\circ} \mathrm{C}$ and standardized to McFarland scale 0.5 . Five wells ( $4 \mathrm{~mm}$ ) were made on the Mueller-Hinton agar plates already seeded with bacteria by spread plate technique using flame sterilized Cork Borer. The essential oils were diluted with Tween 80 to obtain $25 \%, 50 \%$, and $100 \%(\mathrm{v} / \mathrm{v})$ concentrations and $0.1 \mathrm{~mL}$ each was transferred to separate, 
appropriately labelled wells. An aliquot $(0.1 \mathrm{~mL})$ of Tween 80 was used as negative control while streptomycin served as positive control. Plates were incubated at $37^{\circ} \mathrm{C}$ for $24 \mathrm{hrs}$. Antibacterial activity was determined by clearance around loaded wells. MIC was determined as lowest concentration of oil that inhibited growth of bacteria.

\section{RESULTS AND DISCUSSION}

Fresh flowers of Ocimum canum afforded $0.19-0.27 \%(w / w)$ of essential oil. The yield increased from $0.19 \%(\mathrm{w} / \mathrm{w})$ in 7 am harvest to $0.21 \%(\mathrm{w} / \mathrm{w})$ in 10 am harvest. It subsequently decreased to $0.20 \%(\mathrm{w} / \mathrm{w})$ in $1 \mathrm{pm}$ harvest. The yield later increased from $0.24 \%(\mathrm{w} / \mathrm{w})$ in $4 \mathrm{pm}$ harvest to $0.27 \%(\mathrm{w} / \mathrm{w})$ in $7 \mathrm{pm}$ harvest. Variations in oil yields from various harvests signified that the time of harvest affects the yield.

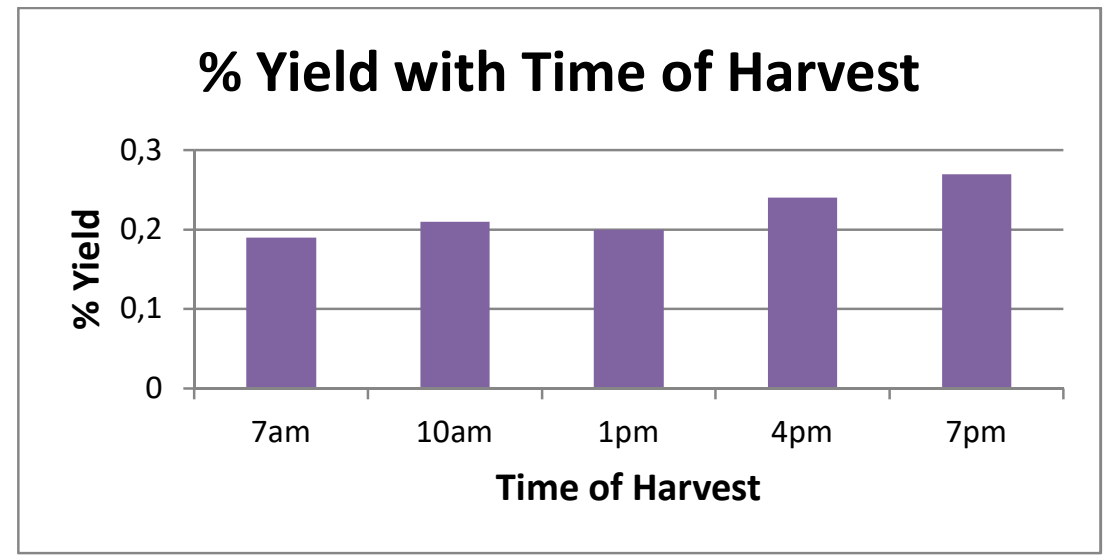

Figure 1: Yield of Oils from Ocimum canum. 
Table 1: Chemical Composition (\%) of Flower Essential Oil of Ocimum canum.

\begin{tabular}{|c|c|c|c|c|c|c|c|c|}
\hline Compound $^{\mathrm{a}}$ & $\mathbf{R I}^{\mathbf{b}}$ & $\mathbf{R I}^{\mathbf{c}}$ & $\%$ Composition & Mass Spectral Data & & & & \\
\hline Car-2-ene & 1001 & 1002 & 2.2 & 0.4 & 0.3 & 0.2 & - & $136,121,105,93,41$ \\
\hline a-terpinene & 1018 & 1015 & - & - & 0.3 & 0.4 & - & $136, \mathbf{1 2 1}, 105,93,77$ \\
\hline$p$-cymene & 1024 & 1024 & 1.3 & - & - & 0.3 & 0.4 & $134, \mathbf{1 1 9}, 103,91,77$ \\
\hline o-cymene & 1026 & 1026 & - & 0.4 & - & - & - & $134, \mathbf{1 1 9}, 105,91,77$ \\
\hline Sylvestrene & 1027 & 1030 & - & 0.3 & 0.5 & - & - & $136,121,107,93,68$ \\
\hline Eucalyptol & 1033 & 1031 & 2.9 & 1.2 & 2.2 & 0.5 & 1.5 & $154,139,108,81,43$ \\
\hline cis- $\beta$-ocimene & 1040 & 1050 & - & 1.0 & 1.7 & 1.1 & 1.0 & $136,121,93,79,41$ \\
\hline Y-terpinene & 1062 & 1059 & - & 0.9 & 0.7 & 0.8 & 0.7 & $136,121,105,93,77$ \\
\hline m-cymenene & 1082 & 1082 & - & 0.5 & - & 0.6 & 0.6 & $134,119,103,91,77$ \\
\hline a-terpinolene & 1088 & 1088 & 0.5 & 0.3 & 0.6 & - & - & $136,121,105,93,79$ \\
\hline Linalool & 1098 & 1096 & 48.1 & 55.4 & 40.5 & 68.1 & 58.7 & $154,121,93,71,41$ \\
\hline Geranial & 1270 & 1268 & 1.6 & 1.8 & 0.6 & 0.9 & 1.1 & $152,109,69,53,41$ \\
\hline Geranyl-formate & 1300 & 1298 & - & - & - & 0.2 & - & $182,136,93, \mathbf{6 9}, 41$ \\
\hline a-cubebene & 1351 & 1351 & 0.1 & 0.2 & 0.1 & - & - & $204,161,119, \mathbf{1 0 5}, 41$ \\
\hline Eugenol & 1356 & 1359 & 8.7 & 8.9 & 6.6 & 4.4 & 4.8 & $\mathbf{1 6 4 , 1 4 9 , 1 3 1 , 1 0 3 , 9 1}$ \\
\hline Nerylacetate & 1365 & 1361 & - & - & 1.5 & - & - & $154,121,93, \mathbf{6 9}, 41$ \\
\hline$\beta$-elemene & 1375 & 1374 & 1.8 & 1.1 & 1.0 & 0.7 & 0.5 & $204,161,121,93,81$ \\
\hline a-copaene & 1376 & 1376 & 1.9 & - & 0.8 & - & - & $204, \mathbf{1 6 1}, 119,105,91$ \\
\hline Geranyl acetate & 1383 & 1382 & - & 0.2 & - & 4.9 & - & $154,121,93, \mathbf{6 9}, 41$ \\
\hline$\beta$-cubebene & 1390 & 1388 & 0.2 & 0.2 & 0.2 & - & - & $204, \mathbf{1 6 1}, 105,91,41$ \\
\hline$\beta$-caryophyllene & 1418 & 1417 & 2.8 & 1.4 & - & - & - & $204,161,133,93,41$ \\
\hline a-trans-bergamotene & 1436 & 1435 & - & - & 9.4 & 3.2 & 5.3 & $204,161,119,93,41$ \\
\hline a-guaine & 1439 & 1439 & 1.7 & 0.8 & 0.8 & 0.5 & 0.6 & $204,161, \mathbf{1 0 5}, 93,41$ \\
\hline (Z)- $\beta$-farnesene & 1443 & 1442 & 2.3 & 0.3 & - & 0.2 & - & $204,133,93,69,41$ \\
\hline
\end{tabular}




\begin{tabular}{|c|c|c|c|c|c|c|c|c|}
\hline$\beta$-chamigrene & 1475 & 1473 & - & - & 1.0 & - & - & $204, \mathbf{1 8 9}, 105,93,41$ \\
\hline y-muurolene & 1477 & 1475 & 1.2 & 0.3 & 1.7 & - & 0.8 & $204, \mathbf{1 6 1}, 119,91,41$ \\
\hline Germacrene D & 1480 & 1479 & 1.5 & 1.4 & 1.7 & - & 1.5 & $204, \mathbf{1 6 1}, 119,105,41$ \\
\hline a-selinene & 1494 & 1494 & - & - & - & 0.5 & - & $204, \mathbf{1 8 9}, 161,133,41$ \\
\hline Bicyclogermacrene & 1494 & 1500 & - & 0.9 & 0.8 & 0.2 & 0.4 & $204,161, \mathbf{1 2 1}, 93,41$ \\
\hline$\beta$-himachalene & 1499 & 1500 & - & - & 0.2 & - & - & $204,134, \mathbf{1 1 9}, 105,41$ \\
\hline a-bulnesene & 1505 & 1509 & 2.4 & 1.3 & 1.2 & 0.4 & 0.6 & 204,189,107,93,41 \\
\hline Amorphene & 1506 & 1511 & - & 0.5 & 1.7 & 0.8 & 0.8 & $204,161, \mathbf{1 3 3}, 105,41$ \\
\hline Y-cadinene & 1513 & 1513 & 0.4 & 1.7 & 0.7 & 1.0 & 1.4 & $204, \mathbf{1 6 1}, 119,91,41$ \\
\hline$\beta$-sesquiphellandrene & 1521 & 1522 & - & 0.5 & 0.4 & 0.8 & 0.7 & $204,161,93,69,41$ \\
\hline cis-nerolidol & 1534 & 1563 & - & - & 1.2 & 0.2 & - & $204,161,136,69,41$ \\
\hline Germacrene B & 1560 & 1561 & 1.6 & - & - & 0.5 & 0.4 & $204,161, \mathbf{1 2 1}, 93,41$ \\
\hline trans-nerolidol & 1564 & 1532 & 0.3 & - & - & 0.2 & - & $204,161,105,69,41$ \\
\hline Spathulenol & 1576 & 1578 & 0.2 & - & - & - & - & $220,205,119,91,43$ \\
\hline Caryophyllene oxide & 1581 & 1583 & - & 0.2 & - & - & - & $219,161,121,79,41$ \\
\hline$\beta$-eudesmol & 1649 & 1650 & 0.2 & 0.2 & 0.1 & - & - & $222,204,189,149,59$ \\
\hline Bisabolol & 1683 & 1685 & 0.2 & - & - & - & - & $204,119,109,69,43$ \\
\hline Patchoulene & 1793 & 1756 & & 0.8 & & & & $204,161, \mathbf{1 0 7}, 93,79$ \\
\hline $\begin{array}{l}\text { TOTAL } \\
\text { No of Compounds }\end{array}$ & & & $\begin{array}{l}92.1 \\
30\end{array}$ & $\begin{array}{l}92.4 \\
37\end{array}$ & $\begin{array}{l}93.7 \\
36\end{array}$ & $\begin{array}{l}98.8 \\
33\end{array}$ & $\begin{array}{l}97.7 \\
25\end{array}$ & \\
\hline
\end{tabular}

No of Compounds a

b:- Retention indices on fused silica capillary column coated with $\mathrm{cp}-\mathrm{sil}^{\mathrm{c}}{ }^{\mathrm{c}}$ :- Retention Indices from literature. 
Identities, retention indices, and percentage composition of the constituents of flower essential oils of Ocimum canum harvested at 3 hours interval in a day ( 7 am, 10 am, 1 pm, 4 pm, and 7 $\mathrm{pm}$ ) is presented in Table 1 . In the table, compounds $25-37$ representing $92.1-98.8 \%$ of the oils were identified from their mass spectra. Hydrocarbon monoterpenoids constituted $6.2-10.2 \%$ of the oils while percentage composition of oxygenated monoterpenoids was $51.2-74.4 \%$. Meanwhile, $1.3-22.0 \%$ of the oils was hydrocarbons and oxygenated sesquiterpenoids.

The most abundant constituent of the oil was linalool (40.5-68.1\%). Other major constituents were limonene $(0.6-7.5 \%)$, terpinen-4-ol $(1.4-5.6 \%)$, eugenol $(4.4-8.9 \%)$, geranyl acetate $(0.2-4.9 \%)$, a-trans-bergamotene $(3.2-9.4 \%)$ and $(E)$-isoeugenol $(4.1-5.5 \%)$. Car-2-ene $(0.2-2.2 \%)$, car-3-ene $(1.2-2.4 \%)$, eucalyptol $(0.5-2.9 \%)$, cis- $\beta$-ocimene $(1.0-1.7 \%)$, octylacetate $(2.4 \%)$, neryl acetate $(1.5 \%)$, $\beta$-elemene $(0.5-1.8 \%)$, a-copaene $(0.8-1.9 \%)$, $\beta$ caryophyllene $(1.4-2.8 \%)$, $\delta$-guaine $(0.5-1.7 \%),(Z)$ - $\beta$-farnesene $(0.2-2.3 \%), \gamma$-muurolene $(0.3-1.7 \%)$, germacrene $D(1.4-1.7 \%)$, a-bulnesene $(0.4-2.4 \%)$, $\gamma$-cadinene $(0.7-1.7 \%)$, cis-nerolidol $(0.2-1.2 \%)$ and germacrene B $(0.4-1.6 \%)$ were also detected in appreciable quantities.

Comparison of the oils revealed that there were variations in their composition patterns. Qualitatively, octyl acetate and bisabolol in the oil from 7 am harvest were not detected in the oils from other harvests. Similarly, oil from 10 am harvest bears $p$-cymene, caryophyllene oxide, and patchoulene that were not found in other oils. Furthermore, the presence of neryl acetate, $\beta$ himachalene and $\beta$-chamigrene were established in the oil of $1 \mathrm{pm}$ harvest but did not exist in other oils. Oil from $4 \mathrm{pm}$ harvest also had geranyl formate, $(E)$ - $\beta$-farnesene, and a-selinene that were not detected in other oils.

Eucalyptol, cis- $\beta$-ocimene, $\gamma$-terpinene, $\beta$-sesquiphellandrene, bicyclogermacrene and amorphene occurred in the oils except for the oil from 7 am harvest. Similarly, limonene, $y$-muurolene and germacrene $D$ were detected in the oils except oil of $4 \mathrm{pm}$ harvest. 2-carene was found in the oils with the exception of the oil of $7 \mathrm{pm}$ harvest. Absence of some compounds in the oils may be due to unfavorable physiological conditions of the plant at the time of harvest that did not favor their biosynthesis.

Quantitatively, linalool was more abundant in the oil of $4 \mathrm{pm}$ harvest than other oils. Similarly, terpinen-4-ol was of greater abundance in the oil of $1 \mathrm{pm}$ harvest than other oils. Geranial and eugenol were more abundant in the oil of 10 am harvest than other oils. $\beta$-Elemene was detected 
in higher quantity in the oil of $7 \mathrm{am}$ and 10 am harvests than other oils. However, $\beta$-cubebene and $\delta$-cadinene were found in higher quantities in the oils of 4 and 7 pm harvests than other oils.

Terpinen-4-ol and eugenol occurred in appreciable quantities in the oils but more abundant in the oils from 7 am and $1 \mathrm{pm}$ harvests, respectively. $\delta$-Guaine was more abundant in the oil of 7 am harvest than other oils. Quantitative variations in the oil constituents are attributable to difference in activity of synthases that mediate the formation of the compounds from their respective precursors (23).

The biosynthesis of terpenoids is usually catalyzed by the synthase of the most abundant monoand sesquiterpenoids in the presence of a divalent metal ion via cationic intermediates. These intermediates subsequently undergo series of reactions such as; hydride shift, cyclization, and other rearrangements until the reaction is terminated by proton loss or hydration to form various terpenoids $(21,23)$. The reactions do proceed by cationic mechanism.

\section{Reaction mechanisms}

The predominance of linalool in the oils implied that its synthase mediates the transformation of geranyl and neryl pyrophosphates to all monoterpenoids in the oils via cationic intermediates (Figure 1). In the figure, linalool synthase aided the transformation of geranyl (1) and neryl pyrophosphates (2) to geranyl (4) and neryl (5) cations. Isomerization of each of the ions (4 and 5) formed linalyl cation (3). Hydration of linalyl and geranyl cations produced linalool (6) in the oils. Hydration of geranyl cation that was oxidized and acetylated gave geranial (8) and geranyl acetate (9) in the oils from 10 am and 4 pm harvests, respectively. Neryl cation (5) was hydrated to nerol (10) in oil from $1 \mathrm{pm}$ and $4 \mathrm{pm}$ harvests and subsequent acetylation of nerol formed neryl acetate (11) in oil from $1 \mathrm{pm}$ harvest. Electrophilic attack of the ion (5) on $\mathrm{C}_{6}-\mathrm{C}_{7}$ double bond produced a-terpinyl cation (12). Deprotonation of the ion (12) at $C_{5}$ and $C_{1}$ followed by its electrophilic attack on the deprotonated carbons formed 3-carene (13) in oil from 7 am to $1 \mathrm{pm}$ harvests and 2-carene (14) in oils from 7 am to 4 pm harvests. Deprotonation of a-terpinyl cation at $C_{8}$ (12) gave limonene (15) in the oils except oil from $4 \mathrm{pm}$ harvest. Folding of the ion (12) towards $C_{2}-C_{3}$ double bond followed by its electrophilic attack via $C_{2}$ produced pinyl cation (16). Deprotonation of the ion (16) at $C_{4}$ formed a-pinene (17) in the oils with the exception of oils from $4 \mathrm{pm}$ and $7 \mathrm{pm}$ harvests. 1, 6-hydride shifts of the ion (12) followed by delocalization of C2 - C3 $n$ electrons to $C 1$ - C2 formed phellandryl cation (18). Deprotonation of the ion (18) at $C_{10}$ formed $\beta$-phellandrene (19) in oils from 10 am and 4 pm harvests. 6 , 7-hydride shift of the ion (12) gives terpinyl-4-yl cation (20). Subsequent deprotonation of the latter (20) at $C_{1}$ and $C_{7}$ 
produced a-terpinene (21) in oils from 1 and $4 \mathrm{pm}$ harvests and a-terpinolene (22) in oils from 7 am, 10 am and $1 \mathrm{pm}$ harvests respectively. Dehydrogenation of a-terpinene (21) at $C_{4}$ and $C_{5}$ formed p-cymene (23) in oil from 10am harvest. Hydration of a-terpinyl cation (12) formed aterpineol (24) in oils from 10am, 4pm and 7pm harvests. Nucleophilic attack of hydroxyl oxygen of a-terpineol on $\mathrm{C} 2-\mathrm{C} 3$ double bond and subsequent protonation of the product formed eucalyptol (25) in the oils.

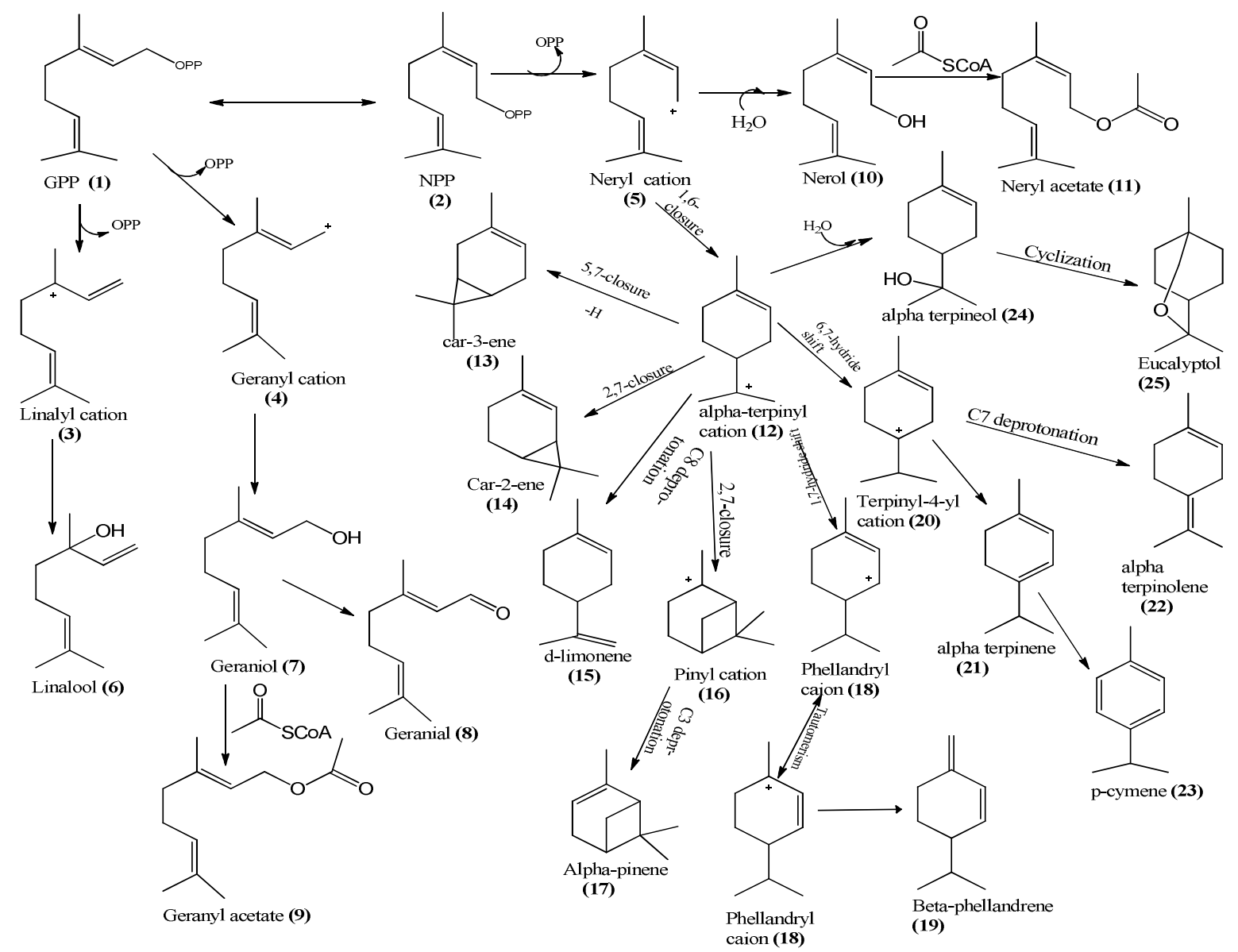

Reaction Scheme 1: Biosynthesis of monoterpenoids mediated by linalool synthase.

The abundance of $\beta$-caryophyllene, $\gamma$-cadinene and $a$-trans-bergamotene in the oils of 7 am, 10 am and 1-7 pm harvests implied that their synthases mediated the biosynthesis of all the sesquiterpenoids in the oils, where each of the compounds predominated (reaction scheme 2 ). In Scheme 2, the synthases catalyzed the ionization of cis- and trans-farnesyl pyrophosphates (27 and 26 ) to their respective cationic intermediates (48 and 49). Isomerization of the ions (48, 49) formed cis- and trans- nerolidyl cations $(\mathbf{5 0}, \mathbf{2 8})$. Hydration of the ions $(\mathbf{5 0}, \mathbf{2 8})$ formed cisnerolidol (51) in oils of $1 \mathrm{pm}$ and $4 \mathrm{pm}$ harvests and trans nerolidol in oils from 7 am and $4 \mathrm{pm}$ 
harvests (29). Electrophilic attack of the ion (48) on $C_{10}-C_{11}$ double bond via $C_{10}$ formed (Z)germacrenyl cation (30). Delocalization of the pi electrons from $C_{6}-C_{7}$ to $C_{6}-C_{5}$ followed by electrophilic addition of the $(E)$-germacrenyl cation (52) on $\mathrm{C}_{2}-\mathrm{C}_{3}$ double bond via $\mathrm{C}_{2}$ formed eudesmanyl cation (31). Bond cleavage at $C_{4}-C_{5}$ followed by deprotonation at $C_{15}$ gave $\beta$-elemene (32) in the oils. Hydride shift followed by electrophilic attack of the ion (30) on the $C_{6}-C_{7}$ double bond via $C_{6}$ formed cadinyl cation (33). Deprotonation of the ion at $C_{3}$ produced $r$-cadinene (34) in the oils. Electrophilic attack of the ion (33) on the $\mathrm{C}_{2}-\mathrm{C}_{3}$ double bond via $\mathrm{C}_{2}$ followed by deprotonation at $\mathrm{C}_{4}$ formed a-copaene (35) in oils from 7 am and $1 \mathrm{pm}$ harvests. Electrophilic attack of (E)-farnesyl cation (48) on $C_{10}-C_{11}$ double bond via $C_{11}$ formed humulyl cation (36). Subsequent electrophyllic attack of the ion (36) on $\mathrm{C}_{2}-\mathrm{C}_{3}$ double bond via $\mathrm{C}_{2}$ formed caryophyllyl cation (37). Deprotonation of the ion (37) at $C_{4}$ and $C_{15}$ form a-caryophyllene (38) and $\beta$ caryophyllene (39) respectively in the oils from 7 am and 10 am harvests. Epoxidation of the compound (39) at $C_{6}-C_{7}$ double bond produced caryophyllene oxide (40) in oil from 10 am harvest. $C_{11}-C_{10}$ and $C_{10}-C_{1}$ hydride shifts followed by delocalization of $C_{2}-C_{3}$ pi electron to $C_{1}-C_{2}$ and subsequent deprotonation at $C_{15}$ of the ion (30) formed germacrene $D(41)$ in the oils with the exception of oil from $4 \mathrm{pm}$ harvest. $\mathrm{C}_{11}-\mathrm{C}_{10}$ and $\mathrm{C}_{10}-\mathrm{C}_{1}$ hydride shifts followed by electrophilic attack of the ion (30) on the $C_{6}$ and $C_{7}$ double bond via $C_{6}$ formed armophenyl cation (42). Deprotonation of the ion (42) at $\mathrm{C}_{8}$ formed a-amorphene (43) in the oils except oil from 7 am harvest. Electrophyllic attack of the (E)-farnesyl cation (49) on $\mathrm{C}_{6}-\mathrm{C}_{7}$ double bond formed bisabolyl cation (46). Electrophyllic attack of the ion (46) on the $C_{2}-C_{3}$ double bond via $C_{2}$ followed by deprotonation at $\mathrm{C}_{4}$ produced a-bergamotene (47) in the oils from 1-7 pm harvests. 


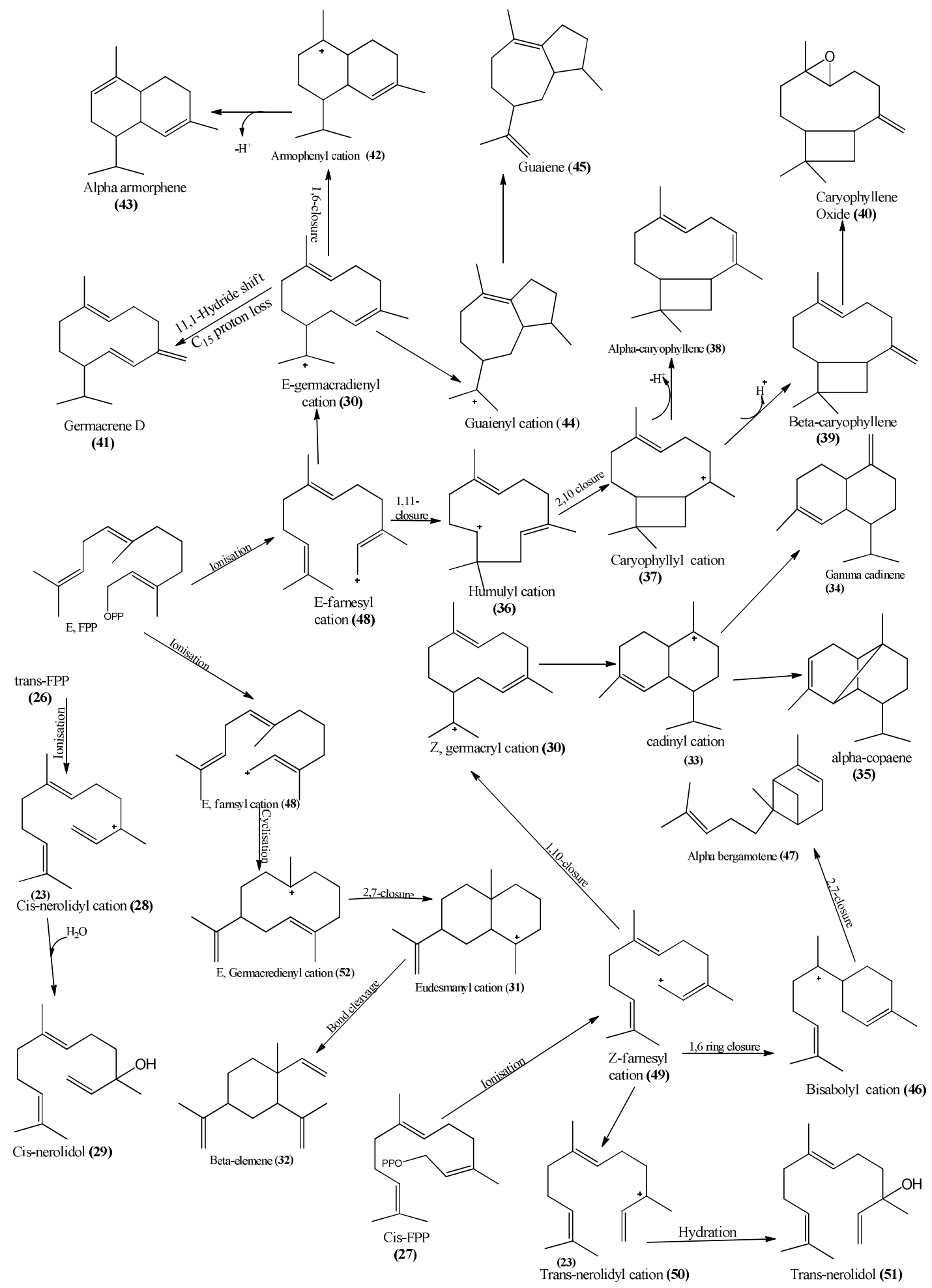

Reaction Scheme 2: Biosynthesis of Sesquiterpenoids mediated by $\beta$-caryophyllene, $\gamma$-cadinene, and a-trans-bergamotene synthases. 
Usman et al., JOTCSA. 2017; 4(1): 149-164.

Table 2: Antibacterial Activity of Fruit Essential Oil of Ocimum Canum Harvested at Different Hour in a Day.

\begin{tabular}{clllll}
\hline $\begin{array}{c}\text { Oil } \\
\text { samples }\end{array}$ & Organisms & \multicolumn{5}{c}{ Activity as Diameter Zone of Clearance Around Bacterial } \\
Colony $\mathbf{( m m )}$
\end{tabular}

KEY: $A=$ Essential oil from 7 am harvest. $B=$ Essential oil from 10 am harvest. $C=$ Essential oil from 1 pm harvest. $D=$ Essential oil from $4 \mathrm{pm}$ harvest. $E=$ Essential oil from $7 \mathrm{pm}$ harvest. S. aureusStaphylococcus aureus. E-coli- Escherichia coli.

The oils inhibited the test organisms at 50 and $100 \%$ concentrations irrespective of the time of collection (Table 2 ). No activity was however obtained at $25 \%$ oil concentration. Activity of the oils compared favorably with that of streptomycin in most of the tests except for sample collected at 7 am where no inhibition occurred at $50 \%$ concentration. Also, Tween 80 , which was the solvent used for dilution, had no inhibitory activity on the test organisms. Judging by the diameter zone of inhibition, Escherichia coli, which is a Gram negative bacteria, was more susceptible to the antibacterial effect of the oils compared to the Gram positive Staphylococcus aureus. This is an indication that the essential oils of $O$. canum may be more active on Gram negative rather than Gram positive organisms. Since activity discriminate based on cell wall type, the mechanism of inhibition by the oil can be likened to that of the $\beta$ lactam antibiotics which inhibits cell wall synthesis. Bassole et al. (15) and Jeferson et al. (12) also reported higher antibacterial activity of oils of $O$. canum on $E$. coli compared to $S$. aureus. 


\section{CONCLUSION}

Essential oil yields from flowers of various harvests differ significantly. This implied that environmental factors and physiological conditions of plants that determine essential oil yield varied at various times of harvest of the flowers, hence, causes differences in their yields. The most abundant monoterpenoid in the oils was linalool of which its synthase aided the formation of all monterpenoids in the oils. However, the composition patterns of monoterpenoids in the oils varied appreciably due to changes in the activity of linalool synthase as determined by environmental and physiological conditions of the plant at various times of harvests. Similarly, $\beta$ caryophyllene, $\mathrm{y}$-cadinene, and a-trans-bergamotene were the most abundant sesquiterpenoids in oils from various harvests. Hence, their synthases mediated the biosynthesis of all sesquiterpenoids in the oils where each of the compounds predominates. Variations in sesquiterpenoids profile in the oils are attributable to differences in activity of the synthases.

The oils were active against Escherichia coli and Staphylococcus aureus. Furthermore, it was noticed that the essential oils of $O$. canum showed higher inhibitory activity against the test organism than the positive control (streptomycin). Although, they were more active against Escherichia coli (gram negative) than Staphylococcus aureus (gram positive) bacteria, concentration and modelling of such oil with inhibitory activity into antibiotics can serve as an intervention to the ever growing problem of antibiotic resistivity.

\section{REFERENCES}

1. Iwu MM, 1993. Handbook of African medicinal plants. CRC Press, New York, pp: 164-166.

2. Ngassoum MB, Ousmaila H, Ngamo LT, Maponmetsem PM, Jirovetz L, Buchbauer G. Aroma compounds of essential oils of two varieties of the spice plant Ocimum canum Sims. From northern Cameroon. J. Food Comp. Anal., 2004; 17: 197-204. DOI: 10.1016/j.jfca.2003.08.002.

3. Bauer K, Garbe D, Surburg H. Common Fragrance and Flavour Materials, 2 edn., VCH Verlagsgesellschaft mbH, Weinheim. 1990.

4. Fun $C E$, Baerheim-Svendsen A. Composition of the essential oils of Ocimum basilicum var. canum Sims and O. gratissimum L. Grown on Aruba. Flavour Frag. J. 1990; 5: 173-177. DOI: 10.1002/ffj.2730050308.

5. Tamil Selvi M, Thirugnanasampandan R, Sundarammal S. Antioxidant and cytotoxic activities of essential oil of Ocimum canum Sims. from India. Journal of Saudi Chemical Society. 2015; 19: 97100. DOI: $10.1016 /$ j.jscs.2011.12.026. 
6. Bhattacharya A, Ashok A, Navnota S, Jagbeer C. Evaluation of some anti-oxidative constituents of three species of Ocimum. International Journal of Life Science. $2014 ; \mathbf{8}(5)$ : 14-17. DOI: 10.3126/ijls.v8i5.11858.

7. Pradyut B. Evaluation of antibacterial activities of leaf extracts of two medicinal plants Ocimum canum Sims and Ocimum tenuiflorum Linn., J. Microbiol. Biotech. Res., 2013; 3 (3):20-23. URL: http://scholarsresearchlibrary.com/JMB-vol3-iss3/JMB-2013-3-3-20-23.pdf.

8. Behera S, Babu SM, Ramani YR, Choudhury PK, Panigrahi R. Phytochemical Investigation And Study On Antioxidant Properties Of Ocimum Canum Hydro-Alcoholic Leaf Extracts. Journal of Drug Delivery \& Therapeutics. 2012: 2(4), 122-128. URL:

http://jddtonline.info/index.php/jddt/article/view/198/133.

9. Ntezurubanza L, Scheffer JJC, Looman A. Composition of the essential oil of Ocimum canum grown in Rwanda. Pharmaceutisch Weekblad Scientific Edition. 1985; 273, Vol. 7.. DOI: 10.1007/BF01959201.

10. Ekundayo O, Laakso I, Hiltunen R. Constituents of the Volatile Oil from Leaves of Ocimum canum Sims. Flavour and fragrance journal. 1989; 4.17-18. DOI: 10.1002/ffj.2730040104.

11. Martins AP, LIgia R, Salgueirol R, Felix T, Salvador C, Joseph C, Antonio PC, Tomás A. Composition of the Essential Oils of Ocimum canum, 0. gratissimum and 0. Minimum, Planta Med., 1999; 65. DOI: $10.1055 / \mathrm{s}-2006-960465$.

12. Jeferson C, Nascimento L, Barbosa CA, Vanderlucia FP, Jorge MD, Renato F, Luiz AMS, Robson SA. Chemical composition and antimicrobial activity of essential oils of Ocimum canum Sims. and Ocimum selloi Benth. Annals of the Brazilian Academy of Sciences. 2010; 83(3): 787-799. DOI: 10.1590/S0001-37652011005000019.

13. Philippe B, Ntonga PA, Eric- Moïse BF, Gisèle AFD, Joseph LT. Chemical composition and residue activities of Ocimum canum Sims and Ocimum basilicum $L$ essential oils on adult female Anopheles funestus SS, Journal of Animal \&Plant Sciences. 2013; 19(1): 2854-2863. URL: http://www.m.elewa.org/JAPS/2013/19.1/4.pdf.

14. Ntonga PA, Nicolas B, Elisabeth M, Lengo M, Philippe B, Philippe G. Activity of Ocimum basilicum, Ocimum canum, and Cymbopogon citratus essential oils against Plasmodium falciparum and maturestage larvae of Anopheles funestus s.s. EDP Sciences Parasite. 2014; 21: 33. DOI: $10.1051 /$ parasite/2014033.

15. Bassole IHN, Nebie R, Savadogo A, Ouattara CT, Barro N, Traore SA. Composition and antimicrobial activities of the leaf and flower essential oils of Lippia chevalieri and Ocimum canum from Burkina Faso. African Journal of Biotechnology. 2005; 4 (10): 1156-1160. URL:

http://www.ajol.info/index.php/ajb/article/view/71260/60215.

16. Usman LA, Watti OI, Ismaeel RO, Ojumoola AO. Effect of drying on yield, chemical composition and Insecticidal activity of leaf essential oil of sweet orange (Citrus sinensis). Journal of the Turkish Chemical Society (JOTCS). 2016; 3(1):1-18. DOI: 10.18596/jotcsa.09331.

17. Saliu BK, Agbabiaka TO, Sule IO, Gambari-Ambali RO. Assessment of Local Methods of Processing for the Preservation of the Physico-Chemical Properties and Microbiological Quality of two Local Cheeses in Ilorin, Nigeria. Journal of Microbiology Biotechnology and Food Science. 2014; 3 (4) 337-342. URL: http://search.proquest.com/docview/1648082027?pq-origsite=gscholar.

18. British Pharmacopoeia, London, H.M. Stationary. 1980; 11: 109. ISBN: 9780113206889.

19. Jennings W, Shibamoto T. Qualitative Analysis of Flavour volatiles by Glass Capillary Gas Chromatography. Academic Press, 1980; New York. ISBN: 0-12-384250-6. 
Usman et al., JOTCSA. 2017; 4(1): 149-164.

20. Adams RP. Identification of Essential Oil components by Gas Chromatography and Mass Spectrometry. 4th ed. Allured Publ. Corp.Carol Stream. IL. USA. 2012; ISBN: 978-1-932633-21-4.

21. Joulain D, Koenig WA. The Atlas of Spectra data of sesquiterpene hydrocarbons. 1998; E.B. Verlog Hamburg, Germany. ISBN: 9783930826483.

22. Sartoratto A, Machado ALM, Delarmelina C, Figueira GM, Duarte MCT, Rehder VLG. Oils from Aromatic Plants used in Brazil. Brazilian J. Microbiology. 2004; 35: 275-280. DOI: 10.1590/S151783822004000300001.

23. Degenhardt J, Kollner TG, Gershenzon J. Monoterpene and sesquiterpene synthases and the origin of terpene skeletal diversity in plants. Phytochem. 2009; 70: 1621-1637. DOI:

10.1016/j.phytochem.2009.07.030. 


\title{
Türkçe Öz ve Anahtar Kelimeler
}

\section{Nijerya'da Yetiştirilen Ocimum canum (Sims) Çiçek Esansiyel Yağının Kimyasal Bileşimi ve Antibakteriyel Aktivitesi Üzerine Toplama Zamanının Etkisi}

\author{
Usman Lamidi Ajao, Yusuf Abdulrauf Olaniyi, Saliu Bola Kudirat, Olanipekun Bolatito Eunice, Elelu \\ Nusirat.
}

Öz: Bir günün farklı zamanlarında (7 öö, 10 öö, 1 ös, 4 ös, 7 ös) hasat edilen Ocimum canum çiçekleri $(1000 \mathrm{~g})$ ayrı ayrı hidrodistilasyona tabi tutulmuş ve \%0,19-0,27 (w/w) esansiyel yağ vermiştir. GC ve GC-MS analizleri, yağların oksijenli monoterpenoidler $(\% 51,2-74,4)$ içerdiğini göstermiştir. Hidrokarbon monoterpenoidleri yağların \%6,2-10,2'sini oluşturmuştur. Hidrokarbon ve oksijenli seskiterpenoidlerin yağlardaki yüzde bileşimi \%1,3-22,0 arasında değişmektedir. Yağlarda en baskın bileşen linalooldür (\%40,5-58,7). Diğer birincil bileşenler şöyle sıralanabilir: Limonen $(\% 0,6-7,5)$, terpinen-4-ol $(\% 1,4-5,6)$, eugenol $(\% 4,4-8,9)$, geranil asetat $(\% 0,2-4,9)$, a-trans-bergamoten $(\% 3,2-9,4)$ ve (E)-izoeugenol (\%4,1-5,5). Linaloolün yağlarda baskın olması, yağların linalool kemotipinde olduğunu göstermiştir. Yağların antibakteriyel aktivitesi Staphylococcus aureus ve Escherichia coli bakterilerine karşı agar diffüzyon yöntemi ile değerlendirilmiştir. Çiçeğin toplandığı zamandan bağımsız olarak, yağların test edilen organizmalara karşı aktif olduğu bulunmuştur. Ancak, bunlar Staphylococcus aureus'a nazaran Escherichia coli'ye karşı daha aktiftir. Yağların organizmalar üzerindeki aktivitesi derişime bağlıdır.

Anahtar kelimeler: Ocimum canum; kemotip; linalool; terpen sentaz; antibakteriyel aktivite.

Sunulma: 29 Eylül 2016. Düzeltme: 25 Ekim 2016. Kabul: 07 Kasım, 2016. 